\title{
REKONSTRUKSI PENDIDIKAN PERPAJAKAN: SUATU KAJIAN KRITIS TENTANG ETIKA PROFESI DALAM PERSPEKTIF KRITIS KI HADJAR DEWANTARA.
}

\author{
Tri Rahayu Widyaningrum \\ Dosen STIE AsiA Malang \\ Iwan Triyuwono \\ Ali Djamhuri
}

\begin{abstract}
Quality education is needed for the improvement of human resources. The contribution given by the education world will color society's behavior. For that education should be able to give birth to the learner in accordance with the needs of the era and have the ideal values of science. Taxation education should not only be technical to give birth to a person capable of calculating taxes according to Law, but also need to have ethical based tax personality aspects. Ethics have an enormous influence and their absence will have a negative impact on the educational outcome own.

Tax issues at various levels of interest have shackled the practice of taxation in the country, it appears not apart from the moral problems that ditenggarai be a source of trouble. Therefore, it is necessary to have ethical content in tax education as a moral principle and guidance of learning. There are 5 informants in this research, all involved in the field of taxation education such as students, teachers, head of taxation department and tax consultant. This research uses the critical paradigm of Ki Hadjar Dewantara as the Father of National Education. The results of this study indicate that the material taxation provided does not have ethical elements. Teaching is only technical skill without taking into account the importance of ethics. In the perspective of Ki Hadjar Dewantara, this model of education is not in accordance with the essence of science itself, where in the educational process it is necessary to plant Budi Pekerti attached to ethics in relation to taxation education as implied in the thought of Ki Hadjar Dewantara.
\end{abstract}

Keywords: Education, Tax, Ethics, Ki Hadjar Dewantara

\section{ABSTRAK}

Pendidikan berkualitas sangat diperlukan bagi peningkatan sumber daya manusia. Sumbangsih yang diberikan oleh dunia pendidikan akan mewarnai perilaku masyarakat. Untuk itu pendidikan harus mampu melahirkan insan pembelajar yang sesuai dengan kebutuhan jaman dan memiliki nilai-nilai ideal dari ilmu pengetahuan. Pendidikan perpajakan seharusnya bukan hanya bersifat teknik untuk melahirkan pribadi berkemampuan menghitung pajak sesuai Undang-Undang, namun juga perlu memiliki aspek kepribadian utuh berdasar pada etika ( ethics base tax education). Etika memiliki pengaruh yang sangat besar dan ketiadaannya akan berdampak negatif terhadap hasil pendidikan itu sendiri.

Selama ini permasalahan pajak di berbagai level kepentingan telah membelenggu praktek perpajakan di tanah air, hal ini muncul tidak terlepas dari persoalan moral yang ditenggarai menjadi sumber masalah. Untuk itu perlu adanya muatan etika dalam pendidikan perpajakan sebagai prinsip moral dan pegangan pembelajaran. Terdapat 5 informan dalam penelitian ini, semuanya berkecimpung dalam bidang pendidikan perpajakan diantaranya sebagai anak didik, pengajar, ketua jurusan perpajakan dan konsultan pajak. Penelitian ini menggunakan paradigma kritis Ki Hadjar Dewantara sebagai Bapak Pendidikan Nasional. Hasil penelitian ini menunjukkan bahwa materi perpajakan yang diberikan belum memiliki unsur etika. Pengajaran hanya bersifat teknikal skill tanpa memperhitungkan pentingnya etika. Dalam perspektif Ki Hadjar Dewantara, Model pendidikan seperti ini tidak sesuai dengan esensi dari ilmu pengetahuan itu sendiri, dimana dalam proses pendidikan perlu adanya penanaman Budi Pekerti yang melekat pada etika dalam kaitannya dengan pendidikan perpajakan seperti yang tersirat dalam pemikiran Ki Hadjar Dewantara.

Kata kunci: Pendidikan, Pajak, Etika, Ki Hadjar Dewantara

\section{PENDAHULUAN}

Pendidikan berkualitas merupakan bagian dari kebutuhan peningkatan sumber daya manusia di masa yang akan datang. Sumbangsih yang diberikan oleh dunia pendidikan akan mewarnai perilaku masyarakat. Untuk itu pendidikan harus mampu melahirkan insan pembelajar yang sesuai dengan kebutuhan jaman dengan nilai-nilai ideal yang diharapkan dan memiliki konsep utuh yang mampu menciptakan kemanfaatan pendidikan sebagai ilmu pengetahuan.

Pendidikan perpajakan bukan hanya sekedar wujud ilmu pengetahuan yang bersifat teknik dan hanya melahirkan pribadi berkemampuan menghitung pajak sesuai ketentuan Undang-Undang, namun juga memiliki aspek kepribadian utuh yang semestinya diwarnai oleh etika yang diharapkan muncul dari proses pendidikan yang ditempuh. Karena etika 
memiliki pengaruh besar terhadap ilmu perpajakan dan ketiadaannya akan memberi dampak negatif terhadap hasil pendidikan itu sendiri.

Selama ini permasalahan pajak di berbagai level kepentingan telah membelenggu praktek perpajakan di tanah air, hal ini muncul tidak terlepas dari persoalan moral yang ditenggarai menjadi sumber masalah. Berbagai kasus perpajakan memperlihatkan betapa roda perpajakan di tanah air minus moralitas dan bertentangan dengan isi UndangUndang Nomor 16 tahun 2009 menyatakan pajak adalah kontribusi wajib kepada negara yang terutang oleh orang pribadi atau badan yang bersifat memaksa berdasarkan Undang-Undang, dengan tidak mendapatkan imbalan secara langsung dan digunakan untuk keperluan negara bagi sebesar-besarnya kemakmuran rakyat. Dengan 2 fungsi yaitu: fungsi anggaran (budgetair), sebagai sumber dana bagi pemerintah, untuk membiayai pengeluaran negara, dan fungsi mengatur (regulerend) sebagai alat pengatur atau melaksanakan pemerintahan dalam bidang sosial ekonomi (Mardiasmo, 2011:1)

Dari kedua fungsi tersebut dapat dipahami bahwa pajak memiliki peran penting bagi negara. Pajak seolah menjadi tiang kokoh pendiri negeri ini. Untuk itu, maka pendidikan perpajakan harus terlaksana dengan baik, mampu menghasilkan masyarakat yang melek pajak dan sekaligus berkualitas dalam sektor perpajakan. Keberhasilan pendidikan perpajakan merupakan salah satu faktor kunci dalam upaya peningkatan penerimaan pajak yang berkesinambungan. Pendidikan pajak sudah seharusnya dibarengi dengan upaya penerapan Ethical base tax education sebagai upaya memperbaiki tax morale. Sebagai suatu komitmen kebaikan bersama melalui pendidikan etika dalam pembelajaran pajak sebagai kerangka keberhasilan dari pendidikan perpajakan itu sendiri. Selama ini, pajak memang sarat dengan persoalan-persoalan fundamental, untuk itu pendidikan pajak harus memainkan peranan penting atas kemampuannya dalam merubah mindset, budaya, serta mempersiapkan ahli pajak yang dapat menjadi motor perubahan demi tercapainya kesadaran masyarakat dalam membayar.

Selama ini pembelajaran pajak lebih terfokus pada upaya pengembangan keterampilan menghitung pajak sebagai upaya memenuhi prasyarat profesi perpajakan. Di Indonesia, sebagian besar pendidikan hanya untuk mengejar sertifikasi konsultan pajak Brevet A, B dan C.

Pendidikan dasar dan sosialisasi pajak memiliki peran besar dalam membentuk apa yang disebut sebagai culture of compliance, akan tetapi, jika upaya pendidikan pajak di Indonesia hanya terbatas pada upaya membentuk culture of compliance, maka kita hanya memiliki individuindividu yang mengekor tanpa memiliki arah dan keteladanan dalam hal perpajakan. Pendidikan perpajakan, dalam hal ini edukasi serta sosialisasi tidak hanya dimaksudkan untuk membentuk seseorang menjadi ahli dalam hal perpajakan namun juga memainkan peran strategis yang dapat mempengaruhi seluk beluk sektor perpajakan, baik dari sisi kebijakan, interpretasi, perumusan hukum, advokasi, sengketa pajak serta hal-hal lain mengenai upaya memenuhi kepatuhan pembayar pajak (www.Dannydarussalam.com).

Begitu luasnya cakupan dari pendidikan perpajakan memicu perlunya pembekalan kode etik dalam pendidikan perpajakan secara utuh, agar tercipta pola pendidikan perpajakan yang utuh, ideal dan berkesinambungan yang hanya akan terwujud apabila berbagai pihak menyadari manfaat etika sebagai pondasi pembelajaran ilmu perpajakan. Dari sisi ketersediaan lapangan kerja dipastikan bahwa terdapat permintaan yang semakin tinggi dari pasar tenaga ahli perpajakan, baik untuk sektor publik dan privat. Target tax ratio sebesar 16\% di tahun 2019 yang dibarengi dengan rasio jumlah pegawai pajak terhadap jumlah penduduk yang masih rendah akan mendorong pemerintah pusat untuk terus menerus melakukan rekrutmen tenaga ahli perpajakan. Hal inilah yang mendorong penulis untuk melakukan penelitian ini. Dengan kata lain sebelum sumber daya manusia yang berkemampuan pajak itu terjun ke dunia kerja, hendaknya mereka dibekali pengetahuan mengenai etika perpajakan sebagai modal awal agar tenaga kerja tersebut bisa melaksanakan tugasnya dengan baik berlandaskan etika yang telah menjadi pondasi dalam skill/kemampuannya di bidang perpajakan (www.Dannydarussalam.com).

Menurut penulis, jika tujuan pendidikan perpajakan hanya berhenti pada batasan kompetensi menghitung pajak, dikhawatirkan membentuk pribadi pajak yang individualis, intelektualis dan materialis. Hal ini dapat memperlebar pelanggaran etika dalam kasus perpajakan. Untuk itu maka perlu penambahan nilai-nilai yang sesuai dengan karakter dan budaya bangsa indonesia melalui rekonstruksi pendidikan perpajakan dalam rangka terciptanya aktor-aktor intelektual yang memiliki budi pekerti luhur.

\section{METODE PENELITIAN}

Penelitian ini merupakan jenis penelitian kualitatif menggunakan paradigma kritis yang memandang realitas sosial sebagai realitas yang kompleks dan peuh konflik. Burrell dan Morgan (1979), paradigma kritis dibagi menjadi dua yaitu radical humanism dan radical structuralism. Radical humanism memandang perubahan dilakukan melalui consciousness (kesadaran) sedangkan radical structuralism memandang perubahan bisa dilakukan melalui perubahan structure atau sistem.

Radical humanism memiliki ciri utama yang khas seperti komitmennya terhadap subyektivitas, 
constructivist dan keyakinan bahwa ilmu pengetahuan seharusnya berfungsi sebagai alat untuk menaikkan harkat kemanusiaan mereka yang tertindas oleh sistem yang ada sekarang (emancipatory), sedangkan radical structuralism bersifat radikal, emansipasi dan potensial dalam suatu analisis yang menekankan pada konflik struktural, mode dominasi, kontradiksi dan pencabutan (Sutriono dan Hanafie, 2007:37).

Dalam bidang akuntansi, Djamhuri (2011) menyatakan bahwa kajian kritis digunakan untuk melakukan emansipasi atau peningkatan derajat mereka yang tertindas dan dirugikan (setidaknya tidak diuntungkan) oleh proses sosial yang menghasilkan atau melibatkan penggunaan informasi akuntansi, baik dalam ranah publik maupun dalam ranah organisasi secara individual .Teori kritis memiliki tujuan untuk mendobrak realitas guna menghilangkan berbagai bentuk dominasi dan mendorong kebebasan, keadilan dan persamaan. Dominasi menyebabkan ketertindasan sebagian manusia. Dominasi dapat berupa sistem demokrasi, hukum pasar, bentuk-bentuk kebudayaan yang memaksakan, ilmu pengetahuan, ideologi bahkan filsafat. Dominasi itu disadari atau tidak disadari telah melahirkan disorientasi nilai, penyimpangan eksistensi, alineasi dan memusnahkan budaya minoritas yang menempatkan manusia pada titik nadir terendah dalam nilai - nilai kemanusiaan (Suka, 2012).

\section{Pemikiran Kritis Ki Hadjar Dewantara}

$\mathrm{Ki}$ Hadjar Dewantara adalah pahlawan nasional dengan Gelar Bapak Pendidikan Nasional. Kepedulian beliau terhadap dunia pendidikan sangat tinggi hal ini terbukti dengan didirikannya Taman Siswa. Proses pendidikan sangat menekankan pada rasa kebangsaan dan mengajarkan peserta didik mencintai bangsa dan tanah air dan berjuang untuk memperoleh kemerdekaan. Keseriusan beliau juga nampak lewat berbagai tulisan dengan tema pendidikan dan kebudayaan berwawasan kebangsaan.

Ki Hadjar Dewantara menjabat Menteri Pendidikan, Pengajaran dan Kebudayaan yang pertama dan ditetapkan sebagai Pahlawan Pergerakan Nasional (Kumalasari, 2010).

Ki Hajar Dewantara juga menyampaikan pepatah bijak yang maknanya sangat dalam. "Ing Ngarso Sung Tulodho" yaitu ketika di depan publik, kita harus bisa memberikan contoh atau teladan yang baik untuk orang lain, "Ing Madyo Mangun Karsa" ketika di tengah atau di antara publik, kita harus mangun karso atau bekerja keras dan membangun kinerja yang baik. "Tut Wuri Handayani" yaitu ketika kita ada di belakang, kita harus memberi semangat dan motivasi untuk orang lain. Tak harus dengan berperang melawan penjajah tetapi dengan kesungguhan melakukan hal positif sesuai profesi masing-masing.

Dalam konteks pendidikan perpajakan, pemikiran Ki Hadjar Dewantara memberi sumbangsih sangat besar.Model pendidikan $\mathrm{Ki}$ Hadjar Dewantara dapat menjadi suri tauladan dari konsep pendidikan yang diharapkan (Wiratmoko, 2011). Rekonstruksi pendidikan perpajakan berdasarkan pemikiran kritis Ki Hadjar Dewantara dengan nilai nilai yang dimiliki dimaksudkan untuk memberi pencerahan dan mampu melahirkan konsep pendidikan bernilai tambah dan kebermanfaatan melalui Ethical tax base education. Rekonstruksi dilakukan melalui nilai budi pekerti yang terdapat dalam pemikiran Ki Hajar Dewantara. Nilai budi pekerti dimaksudkan anak didik memiliki budi pekerti luhur dan beretika. Ki Hadjar Dewantara, sebagai pejuang pendidikan selalu berusaha memperjuangkan kemerdekaan Indonesia melalui pemikiran kritis dengan mengobarkan semangat perjuangan.

\section{Tujuan Pendidikan Ki Hadjar Dewantara}

Tujuan pendidikan Ki Hadjar Dewantara menurut Ekasari,2012 ada empat yaitu; pertama, pendidikan harus dapat membuat keadaan menjadi senang (rahayu) dalam hidup batin, sehingga tercipta rasa puas dan rasa tentram. Kedua, pendidikan juga harus membuat peserta didik bahagia (sebagai individu). Ketiga, tingkat kebahagiaan yang diperoleh pendidikan setiap orang berbeda dan yang keempat, pendidikan dinyatakan sebagai tuntunan dalam kehidupan.

Dari pokok pikiran tersebut dapat kita ambil pelajaran berharga bahwa dalam proses pendidikan tidak diperkenankan adanya unsur keterpaksaan dari berbagai pihak yang terkait di dalamnya, baik itu pemerintah, pendidik maupun peserta didik. Materi yang disampaikan juga perlu dikaji lebih dalam apakah ada unsur-unsur yang dapat merusak akidah agama dan budaya bangsa. Potensi dasar yang dimiliki oleh peserta didik sangat dipengaruhi oleh proses pendidikan yang didapat.pendidikan budi pekerti atau yang biasa disebut akhlak akan membuat manusia dapat menghormati dan menghargai manusia lainnya (Putri;2012).

\section{Informan dalam Penelitian}

Informan dalam penelitian ini adalah orang yang dimanfaatkan guna memberikan informasi mengenai situasi dan kondisi. Untuk pemilihan siapa yang akan menjadi informan, peneliti wajib memahami posisi dengan beragam peran dan keterlibatannya dengan kemungkinan akses infmasi yang dimilikinya sesuai dengan kebutuhan penelitiannya (Sutopo:2002).

Informan dalam penelitian ini adalah aktor yang terlibat dalam proses pendidikan perpajakan dan sangat memahami pendidikan perpajakan yang 
seharusnya sehingga diharapkan para informan memiliki pengetahuan yang mendalam berkaitan dengan fokus penelitian ini.

\section{Nilai budi pekerti}

Nilai Merupakan sesuatu yang berharga baik menurut standar logika (baik-jelek), estetika (bagusburuk), etika (adil-tidak adil), agama (harap-halal), dan hukum (sah-absah), serta menjadi acuan dari sistem keyakinan maupun kehidupan" (Suyatno,2012:36). Selain itu nilai juga dapat diartikan sebagai sifat-sifat (hal-hal) yang penting dan berguna bagi kemanusian, sesuatu yang menyempurnakan manusia sesuai dengan hekekatnya (www.kbbi.com). Istilah "nilai” digunakan untuk menggali pemikiran-pemikiran Ki Hadjar Dewantara.

Nilai budi pekerti merupakan perwujudan keseimbangan Tri-sakti jiwa (cipta, rasa, karsa) demi menjunjung tinggi derajat kemanusiaan. Ki Hadjar Dewantara memiliki budi pekerti dan kecerdasan intelektual yang menjadikanya suri tauladan dan dihormati anak didik, teman bahkan beberapa petinggi Negara Belanda. Tulisan-tulisan beliau mencerminkan seorang putra bangsa yang berbudi luhur. Menurut beliau, Budi pekerti, merupakan tindakan yang selalu memikir-mikirkan, merasarasakan dan berkehendak dengan timbangan kesucian moril, bahwa segala tingkah laku manusia harus senantiasa beradab, sopan, teratur, halus. Budi pekerti yang baik dapat membawa kita menjadi pribadi yang tertib, sopan dan halus perangainya. Budi pekerti yang baik yang diperoleh melalui ilmu pengetahuan dapat menyelamatkan dunia serta melenyapkan kebiadapan.

Dalam pandangan Ki Hadjar Dewantara, budi pekerti adalah jiwa dari pengajaran. Budi pekerti bukan hanya bersifat teoritis namun juga mengandung arti kejiwaan atau perikeadaban manusia secara luas dan mendalam melalui pembiasaan untuk melakukan perbuatan terpuji. Budi pekerti bukan hanya mengajarkan teori tentang baik buruk namun juga pembiasaan berbuat baik dalam keseharian.Untuk itu maka materi pengajaran apapun harus terintegrasi dengan budi pekerti, selaras dengan jiwa kebangsaan menuju pada kesucian, ketertiban dan kedamaian lahir batin (Muthoifin;2015). Dari uraian tersebut terlihat jelas bahwa pendidikan budi pekerti diarahkan pada pembentukan karakter bangsa yang sesuai dengan nilai-nilai agama dan budaya bangsa memiliki kepribadian yang khas, tidak meniru atau bersikap kebarat-baratan dan sebagainya.

Bahkan dalam penelitiannya, Bakhtiar (2015) menjelaskan bahwa Ki Hadjar Dewantara menjelaskan secara rinci komponen inti yang membentuk manusia yang disebut dengan "tri-sakti" jiwa (Cipta,Rasa dan Karsa), dengan penjelasan sebagai berikut;
"Cipta" adalah daya berfikir, bertugas mencari kebenaran sesuatu, dengan jalan membanding-bandingkan barang atau keadaan yang satu dengan yang lain, hingga dapat mengetahui bedanya dan samanya. "Rasa" adalah segala gerak gerik hati kita, yang menyebabkan kita mau tidak mau, merasa senang atau susah, sedih atau gembira, malu atau bangga, puas atau kecewa, berani atau takut, marah atau belas-kasihan, benci atau cinta, begitu seterusnya. "Karsa" adalah kemauan yang selalu timbul di samping dan seakan-akan sebagai hasil buah fikiran dan perasaan. "Kemauan" merupakan lanjutan dari hawa nafsu kodrati yang ada di dalam jiwa manusia, namun sudah dipertimbangkan oleh fikiran serta diperhalus oleg perasaan. Kemauan adalah permulaan segala perbuatan dan tindakan yang pasti dan tertentu daripada manusia yang berbudi.

Keseimbangan dari ketiga konsep tersebut dapat menjadikan manusia memiliki kepribadian yang utuh, tidak terpisah-pisah antara dunia meterial dan spiritual dengan catatan nilai-nilai tersebut disampaikan kepada anak didik agar menjadi manusia yang adil, bersusil dan beradab. Selain itu penanaman budi pekerti melalui pendidikan agar peserta didik tidak terjebak dalam kekuatan pikiran sebagai sumber dari segala inspirasi dan solusi dari permasalahan yang dihadapi.menurut peneliti pikiran bukanlah satu satunya "alat" untuk mengembangkan pemikiran dan kecerdasan konseptual. Untuk itu perlu adanya keseimbangan dalam membentuk kepribadian yang berbudi dan bersusila melalui kekuatan pikiran serta halusnya perasaan (budi pekerti).

Berikut kutipan Ki Hadjar Dewantara yang berkaitan dengan budi pekerti.

"Pendidikan yang menekankan pada aspek intelektual belaka hanya menjauhkan peserta didik dari masyarakatnya dan pendidikan yang ada sekarang hanya menekankan pada pengembangan daya cipta dan kurang memperhatikan pengembangan olah rasa dan karsa. Jika ini berlanjut terus pendidikan hanya akan menjadikan manusia kurang humanis dan manusiawi".(Suparto,2016:83).

Dari kalimat tersebut menunjukkan bahwa dari sisi idealisme, Ki Hadjar Dewantara berkeinginan mewujudkan tatanan kehidupan manusia yang berbudi luhur yang dapat dicapai tidak hanya melalui kecerdasan akal dan pikiran melainkan juga melalui kehalusan budi dan kematangan jiwa. Untuk itu dengan menghilangkan sifat intelektualisme yang memiliki nilai negatif maka dengan sendirinya dampak negatif dari intelektualisme akan berkurang.

Lebih lanjut lagi, dengan pendidikan dan pengajaran budi pekerti ini kepada peserta didik, maka dampak positif yang muncul adalah manusia didik akan menjadi manusia yang terbebaskan dari belenggu kehidupan. Setiap individu akan merdeka dan mandiri seperti pernyataan Ki Hadjar Berikut ini; 
"Pendidikan hendaknya membantu peserta didik untuk menjadi merdeka dan independen secara fisik, mental dan spiritual; pendidikan hendaknya tidak hanya mengembangkan aspek intelektual sebab akan memisahkan dari orang kebanyakan; pendidikan hendaknya memperkaya setiap individu tetapi perbedaan antara masing-masing pribadi harus tetap dipertimbangkan; pendidikan hendaknya memperkuat rasa percaya diri, mengembangkan harga diri; setiap orang harus hidup sederhana dan guru hendaknya rela mengorbankan kepentingan pribadinya demi kebahagiaan peserta didiknya"(Suparto,2016:85)

Dalam pemikirannya, Rahman (2011:42) menyatakan bahwa "Budi pekerti yang baik merupakan cerminan manusia yang berjiwa luhur yang diwujudkan dalam sikap dan perbuatannya yang mulia”. Untuk mensintesiskan nilai budi pekerti, Berikut substansi pemikiran Ki Hadjar Dewantara sebagai pedoman melihat realitas pendidikan perpajakan di lembaga pendidikan profesi dan sebagai landasan merekonstruksi tujuan dari pendidikan perpajakan.

Tabel 3.1 Substansi Nilai Budi Pekerti

\begin{tabular}{|l|l|}
\hline \multirow{2}{*}{$\begin{array}{l}\text { Nilai } \\
\text { Budi } \\
\text { Pekerti }\end{array}$} & \multicolumn{2}{|c|}{ Substansi } \\
\cline { 2 - 3 } & $\begin{array}{l}\text { Keseimbangan cipta, rasa, } \\
\text { karsa (Tri-sakti) jiwa }\end{array}$ \\
\cline { 2 - 3 } & \begin{tabular}{l} 
2. $\begin{array}{l}\text { Mempertinggi derajat } \\
\text { kemanusiaan }\end{array}$ \\
\hline
\end{tabular} \\
\hline
\end{tabular}

\section{HASIL DAN PEMBAHASAN}

Gambaran secara umum mengenai realitas pendidikan perpajakan di situs penelitian selama ini, lebih banyak mengedepankan kompetensi keahlian dan rasionalitas tanpa diimbangi pemikiran mengenai hakekat bentuk dan substansi ilmu perpajakan itu sendiri. Selain itu dari segi karakter materi pajak kurang terlihat moral dan etika sebagai bentuk keadilan, kejujuran serta humanisme. Kondisi ini dikhawatirkan memunculkan sumber daya manusia yang rentan melakukan manipulasi pajak dan kasus pelanggaran etika lainnya.

Ketika saya mewawancarai setiap informan untuk menggali realitas pendidikan perpajakan saat ini, hampir semua informan, belum mengetahui adanya standar dalam pendidikan perpajakan dan manfaat pembelajaran etika pada materi pajak (ethics base tax education).

Seperti yang disampaikan Bapak BB sebagai salah satu informan;

"Nilai budi pekerti dalam jiwa seseorang akan mampu melahirkan jiwa toleransi, saling menolong dan senantiasa berkeinginan untuk berbuat kebajikan."

Selain itu beliau juga menambahkan ;
"Pajak mendidik orang mampu memiliki jiwa toleransi, penolong terhadap semua warga negara, karena didalam membangun negara agar kehidupan masyarakat adil dan makmur butuh bantuan atau kerjasama dari golongan orang-orang kaya, karena pajak hanya dikenakan terhadap orang-orang yang memiliki kekayaan berlebih untuk disumbangkan kepada negara, sedangkan si miskin yang penghasilannya di bawah Penghasilan Tidak Kena Pajak (PTKP), tidak kena pajak”.

Senada dengan Bapak BB, Bapak HR juga menjelaskan :

“....keberadaan budi pekerti dalam pendidikan pajak akan memberi pelajaran bagaimana anak didik belajar konsekwen dengan diri sendiri, siap menghadapi resiko dan siap membentengi diri dari hal-hal yang kurang terpuji”.

Selain itu informan EG juga menyampaikan; "Menurut pendapat saya, penerapan etika dari sisi budi pekerti itu lebih mengacu pada karakter orang yang melakukan pekerjaan. Bukan mengacu pada pengambilan keputusan dalam pekerjaan itu sendiri. Etika memang diperlukan dalam segala bidang profesi, baik untuk subjek pajak maupun fiskus pajak itu sendiri. Masyarakat harus menyadari akan hak dan kewajibannya dengan menerapkan sistem self assesment system yaitu sistem yang mewajibkan dan memberi wewenang kepada setiap wajib pajaknya untuk menghitung, mengisi, membayar dan melaporkan sendiri jumlah pajaknya. System ini akan menyadarkan wajib pajak akan semua kewajiban perpajakannya, memiliki kesadaran yang tinggi dan kejujuran dalam menghitung kewajiban pajaknya".

Dari para informan tersebut dapat diambil benang merah betapa pentingnya esensi etika dalam melahirkan manusia yang beradab dan bersusila, seperti ajaran Ki Hadjar Dewantara yang terekam dalam kalimat berikut:

"Tujuan pendidikan adalah memanusiakan manusia, pendidikan hendaknya menghasilkan pribadi-pribadi yang lebih manusiawi, berguna dan berpengaruh di masyarakat, yang bertanggungjawab atas hidup sendiri dan orang lain, yang berwatak luhur dan berkeahlian”. (Ki Hadjar Dewantara,2016:86)

Selain itu menurut bapak TD, selaku fiskus dan pendidik pajak, ketika saya menanyakan mengenai figur Ki Hadjar Dewantara beliau juga menyatakan,

“ Ki Hadjar Dewantara memang salah satu penjuang yang tangguh, aktif di bidang pendidikan. Pengajaran beliau sesuai dengan 
kharakter pendidikan itu sendiri yaitu memberikan pemahaman yang utuh. Tidak frontal dan bisa diterima oleh semua pihak.memberikan nilai moral, etika secara utuh, tidak hanya cangkang luarnya saja.

Di sisi lain, dari sumber www.dannydarussalam.com menjelaskan sebagai berikut

"Sistem pendidikan pajak yang baik tidak hanya menghasilkan sumber daya manusia yang melek pajak, namun juga ahli-ahli di bidang pajak yang akan menjadi lokomotif reformasi dan transformasi sistem pajak ke arah yang lebih baik. Upaya-upaya membangun sistem pendidikan pajak yang baik kerap dikesampingkan, mengingat bahwa output-nya tidak bisa langsung dinikmati dan membutuhkan proses panjang. Walau demikian, perubahan arah sektor perpajakan di Indonesia dewasa ini akan berpengaruh secara langsung pada lonjakan permintaan atas ahli di bidang pajak. Momentum ini seharusnya dapat dimanfaatkan oleh lembaga pendidikan pajak, khususnya perguruan tinggi”.

Jika konsep pendidikan perpajakan ditujukan untuk membentuk anak didik yang kompeten dan ahli di bidangnya, maka hal ini dapat diartikan bahwa kompetensi rasional sepertinya lebih diutamakan daripada nilai-nilai fundamental yang seharusnya menjadi esensi dalam proses pendidikan akuntansi. Hal ini tentu saja tidak sesuai dengan pemikiran kritis Ki Hadjar Dewantara karena beliau lebih mengutamakan nilai-nilai luhur sebagai penyeimbang kecerdasan peserta didik. Andaikata hal seperti ini dibiarkan terus maka nilai-nilai pendidikan yang dapat merusak kepribadian dan jati diri peserta didik akan berkembang pesat. Beberapa nilai tersebut diantaranya; materialisme, individualisme, egoisme, rasionalisme dan terkikisnya nasionalisme. Inilah yang menjadi kekhawatiran Ki Hadjar Dewantara sebagai sosok guru bangsa yang sangat menjunjung tinggi nilai-nilai keluhuran dan memiliki jati diri bangsa yang beradab dan bersusila.

Pendidikan perpajakan merupakan merupakan kajian bidang perpajakan yang mencakup seluruh elemen di dalamnya. Elemen tersebut meliputi tujuan pendidikan (filosofi), imu perpajakan (materi), pendidik, peserta didik, metode pembelajaran dan sebagainya. Dengan perbaikan tujuan pendidikan perpajakan maka dapat mengarahkan peserta didik tidak hanya memiliki kecerdasan di bidang perpajakan, namun juga senantiasa menjunjung tingi nilai-nilai, moral dan spiritual dalam menjalani dunia kerja.

Keinginan lainnya adalah pembelajaran perpajakan sesuai dengan Statements on Standards for Tax Services merupakan pertimbangan etika umum yang mendasari standar yang dibuat oleh Tax Executive Committee of the AICPA . SSTS diiinterpretasikan sejak 1 Oktober 2000. Dalam kalimat pembukaannya, SSTS menyatakan Anggota harus memenuhi tanggungjawabnya sebagai profesional dengan mendukung dan mempertahankan standar yang dengan itu kinerja profesionalnya bisa diukur". Terdapat Ada 6 (enam) standar yang ditunjukkan dalam SSTS, diantaranya:

1.Seorang akuntan pajak tidak boleh menyarankan sebuah posisi kecuali ada kemungkinan realistik untuk kebaikan yang berkelanjutan.

2.Seorang akuntan pajak tidak boleh membuat atau menandatangani return jika ini berada dalam posisi yang tidak boleh disarankan

3.Seorang akuntan pajak dapat menyarankan sebuah posisi yang menurutnya tidak ceroboh selama ini bisa didisklosur.

4.Seorang akuntan pajak berkewajiban untuk menasehati klien tentang potensi hukuman di beberapa posisi, dan menyarankan disklosur.

5.Seorang akuntan pajak tidak boleh menyarankan sebuah posisi yang "mengeksploitasi" proses seleksi audit IRS atau;

6. Dilarang bertindak sekadar dalam posisi "membantah"

Dalam konteks penelitian ini, tujuan pendidikan pajak merupakan sebuah ide atau gagasan yang bersifat abstrak dan digunakan sebagai landasan dalam pelaksanaan pendidikan perpajakan. Jika tujuan pendidikan perpajakan dapat diinternalisasi nilai-nilai pemikiran Ki Hadjar Dewantara, maka tujuan pendidikan perpajakan akan mencerminkan nilai-nilai kritis $\mathrm{Ki}$ Hadjar Dewantara, dengan demikian peserta didik memiliki kecerdasan dan kompetensi yang kompleks yaitu di wilayah rasionalitas, kritik, intuisi dan spiritual. Keempat poin ini yang akan membentuk pribadi peserta didik lebih utuh (holistik) dengan tidak mengedepankan salah satu dari kompetensi tersebut melainkan berjalan berimbang beriringan.

Nilai budi pekerti merupakan cerminan Trisakti jiwa yaitu cipta, rasa dan karsa demi mempertinggi derajat kemanusiaan yang pada hakekatnya adalah rasa cinta pada budi pekerti yang luhur. Untuk itu secara garis besar keberadaan pendidikan perpajakan yang utuh merupakan cita-cita luhur untuk perkembangan ilmu dan pendidikan di masa yang akan datang. Selain itu tujuan pendidikan perpajakan yang baru merupakan usaha untuk membentuk manusia yang sempurna dengan mensucikan lahir batin melalui nilai budi pekerti yang merupakan cita-cita luhur dan harus diperjuangkan bersama dalam ranah pendidikan perpajakan demi terwujudnya pendidikan perpajakan yang ideal dalam perspektif Ki Hadjar Dewantara. 


\section{SIMPULAN DAN SARAN}

Hasil penelitian ini menyimpulkan bahwa perlu adanya Ethics tax base education guna mencegah terjadinya perilaku negatif dari praktek perpajakan seperti misalnya nilai intelektualitas, materialisme, individualisme, egoisme yang makin berkembang dan dapat mengikis rasa nasionalisme. Penelusuran kembali tujuan dari pendidikan perpajakan perlu dilakukan untuk menyesuaikan esensi pajak itu sendiri, yaitu dari rakyat, oleh rakyat dan untuk rakyat. Pendidikan pajak perlu di Rekonstruksi ulang dan disesuaikan dengan karakteristik dan budaya bangsa Indonesia melalui nilai budi pekerti yang memiliki esensi bersatunya tri-sakti (cipta-rasa-karsa) untuk mempertinggi derajat kemanusiaan.

Rekonstruksi pendidikan perpajakan diperlukan untuk menetralisir dampak negatif yang muncul. Rumusan pendidikan perpajakan harus diarahkan untuk membentuk manusia sempurna secara lahir batin melalui nilai budi pekerti. Kesempurnaan inilah yang menjadi substansi dari tujuan pendidikan perpajakan di lembaga pendidikan Profesi Wearnes Education Center sesuai cita-cita luhur Ki Hadjar Dewantara dalam mewujudkan peradaban manusia yang bersusila, adil dan beradab.

\section{DAFTAR PUSTAKA}

1. Amirya, Mirna, Ali Djamhuri, Unti Ludigdo, 2011, Pengembangan Sistem Anggaran dan Akuntansi Badan Layanan Umum Universitas Brawiajaya: Sebuah Studi Interpretif. Universitas Brawijaya, Malang.

2. Ardi Mulia, Etika perpajakan berbasis etika Pancasila, Jurnal Madani Edisi I/ Mei 2012..

3. Ayu Intan, Konsep Pendidikan Humanistik Ki Hadjar Dewantara dalam pandangan Islam, 2012, Tesis, Institut Agama Islam Negeri (IAIN) Walisongo.

4. Burrell, G dan G. Morgan, 1979, Sociological Paradigms and Organisational Analysis: Elements of The Sociology of Corporate Life. Heinemann Educational Books, London.

5. Dewantara, Ki Hadjar,1967. Bagian IIA: Kebudajaan. Diterbitkan oleh Madjelis Luhur Persatuan Taman Siswa. Ditjetak oleh Pertjetakan Taman Siswa. Jogyakarta.

6. Dewantara, Ki Hadjar. 1977. Bagian I: Pendidikan. Cetakan kedua. Diterbitkan oleh Madjelis-Luhur Persatuan Taman Siswa. Jogyakarta.

7. Ekasari, K. 2012.(Re)Konstruksi Pendidikan Akuntansi di Tingkat Pendidikan Vokasi, Melalui Epistimologi 3ling. Disertasi. Program Doktor Ilmu Akuntansi, Program Pascasarjana Fakultas Ekonomi dan Bisnis, Universitas Brawijaya.
8. Kamayanti, A. 2016, Metodologi Penelitian Kualitatif Akuntansi, Yayasan rumah paneleh, Jakarta, cetakan 2.

9. Moleong, Lexy (2009). Metodologi Penelitian Kualitatif ,Bandung. PT. RosdaKarya.

10. Mustofa, Bisri. (2008). Metode Menulis Skripsi dan Tesis. Yogyakarta: Optimus.

11. Pohan, Imbalo S. 2007. Jaminan Mutu Layanan Kesehatan: Dasar-Dasar Pengertian dan Penerapan. Jakarta. Penerbit Buku Kedokteran EGC.

12. Prastowo. 2010. Menguasai Teknik-teknik Koleksi Data Penelitian Kualitatif. Jogjakarta: DIVA Press.

13. Prastowo, Andi. 2012. Panduan Kreatif Membuat Bahan Ajar Inovatif. Jogjakarta: Diva Press.

14. Rahardjo Suparto, 2016, Biografi singkat Ki Hajar Dewantara, Jogyakarta, Garasi.

15. Rahman, Fathor. 2011. Analisis Sistem Pengendalian Intern dengan perspektif Spiritualisme Islam. Skripsi. Fakultas Ekonomi dan Bisnis, Universitas Brawijaya.

16. Riharjo, Ikhsan Budi, Memahami paradigma penelitian Non-positivisme dan implikasinya dalam penelitian akuntansi, jurnal akuntansi, Managemen dan sektor publik(JAMBSP), vol. 8 No. 1-oktober 2011:128-146.

17. Salampessy, Zulkarim. (2011). Pengaruh Dana Alokasi Umum (DAU) dan Pendapatan Asli Daerah (PAD) Terhadap Belanja Daerah, Jurnal Ekonomi dan Manajemen, Vol 2 No 1, Oktober, hal 19-29, Universitas Pattimura, Ambon.

18. Suka, G. 2012. Dominasi Dalam perspektif Teori Kritis. Jurnal Pustaka Volume XII, No. 1, februari 2012.

19. Sutriono dan Hanafie, S.R (2007). Filsafat Ilmu dan Metodologi Penelitian, Yogyakarta: Andi Offset.

20. Suyanto, Bagong dan Sutinah. 2005. Metode Penelitian Sosial: Berbagai Alternatif Pendekatan. Jakarta: Kencana.

21. Undang-Undang nomer 16 tahun 2009 tentang pengertian pajak.

22. Triyuwono I. Akuntansi Syariah dan Koperasi Mencari Bentuk dalam Bingkai Metafora Amanah, Jurnal Akuntansi dan Auditing Indonesia, Vol. 1,1997.

23. www.Dannydarussalam.com

24. ww.Kbbi.web.id

25. www.Liputan6.com

26. www.ortax.org

27. www.Pajak.go.id 